\title{
ASSESSMENT ON \\ THE ISLAMIC BANKING MARKET SHARE PROJECTION BY BANK INDONESIA AND PROPOSED METHODS
}

\author{
Raditya Sukmana ${ }^{1}$ \\ Heri Kuswanto
}

\begin{abstract}
Indonesian Islamic banking market share projected by Bank Indonesia is an integral part in developing the industry in the country. By setting a projection which will then be used as a benchmark / target, Islamic banks can make a necessary program to attract new customers which eventually increase its asset. If the increase of the asset is significant, the Islamic bank market share may increase. The problem is that the current projection by Bank Indonesia seems to be off target. It means that the projection is pretty much above the actual value. This paper attempts to utilize two projection methods namely Spline and Auto-ARIMA which we think can provide a better result. This study uses the monthly data covering period since January 2006 until December 2012. The result shows that our projections, especially using Spline method, are closer to the actual value of the Islamic banking industry market share. It means that the gap between the projection and the actual value of market share is lesser than the gap on the Bank Indonesia calculation. Moreover, this study argue that, the projection of the Islamic banking market share made by $\mathrm{BI}$ will not be achieved unless with government support. So far, government has not made any policy which deposit some of the national budget in the Islamic bank. This study calculates that if government regularly depositing $1 \%$ of total National Government Budget in Islamic banks, the projection of Islamic banking market share made by $\mathrm{BI}$ will be acheived. As a conclusion, the role of government is very significant in developing the Islamic banking industry in Indonesia.
\end{abstract}

Keywords: Market share Islamic Bank, Spline, Auto-Arima JEL Classification: E44, E47

1 Raditya Sukmana is Head of Master Science in Islamic Economic Program Universitas Airlangga, Surabaya (momyadit@gmail.com); Heri Kuswanto is Lecturer at the Department of Statistics, Institut Teknologi Sepuluh Nopember, Surabaya (Kuswanto.its@gmail.com) 


\section{INTRODUCTION}

Although the Muslim population in Indonesia reaches around 87.18 in 2010 (Census, 2010) the establishment of Islamic banks was relatively late as compare to the neighbouring country, Malaysia which established the first Islamic bank in 1982. The first Islamic bank in Indonesia namely Bank Muamalat Indonesia (BMI), which was established in 1st November 1991, was highly supported by the then President of Indonesia, Suharto. Islamic Banking Act of Indonesia was enacted in 2008 and effectively started on 2010. Previously, the existing Islamic banks are under the revision of the conventional banking act which mentions that the banks have been allowed to operate other types of banking system which does not use interest. Besides Islamic banks, there exists also the Islamic Rural Banks and Islamic Banking Units (LPPS 2007, p xix).

Eight years after the establishment of the first Islamic bank, the second Islamic bank known as Bank Syariah Mandiri was established. It was a conversion of the conventional bank, Bank Susila Bakti. In the same year, Islamic Banking Unit was established. It is a unit within conventional banks which offer Islamic banking products. However, the difference between Malaysia and Indonesia is that Malaysia uses Islamic windows, whereby within the office of conventional banks, there exists a different counter for Islamic banking products. In Indonesia, conventional banks would normally have a separate building as well as separate management.

Bank Muamalat performed good in the early years of its commencement. In the second year of its existence, deposit increased from 20,800 million Rupiah in 1992 to 60,320 million in 1993. Similarly, financing also increased very significantly, from 32,650 million Rupiah to 92,000 million Rupiah in the subsequent year (Table 1). The following years, BMI was able to maintain good performance. However, the Asian crisis in 1997 created damage to the banking system. Not only did the conventional banks suffer, Islamic Banks were also affected. Table 1 shows that in 1998, Islamic banking assets, financing and deposit were declining very significantly. Growth of those three indicators shows contractions of $18.3 \%, 30.5 \%$ and $15.4 \%$, respectively. 
At that time, Bank Indonesia had to increase the interest rate in a significant rate to prevent further deterioration of the Rupiah due to capital flight. Consequently, this high interest rate caused the withdrawal of funds from the Islamic banks to conventional banks. This kind of situation known as the displacement commercial risk had to be faced by Islamic banks. It is the risk whereby depositors withdraw their money from Islamic banks and put it in the conventional banks due to more attractive interest rates given by their conventional counterparts. Nevertheless, in 1999, Islamic banks were able to recover. Asset, Financing and Deposit increased to $44.5 \%$, $8.05 \%$ and $34.7 \%$, respectively.

The growth of Islamic banks in Indonesia, although increased significantly in the nominal term, did not increase in terms of the percentage share of the total banking asset. In 2000, total Islamic banking assets amounted to Rp 1,790,168 million and that amount accounted for only $0.17 \%$ of total banking assets. 2004 marked the year in which the proportion of Islamic banking assets out of total banking assets reached beyond 1\% (Islamic Banking Statistics, August 2004). In 2011, the asset, financing as well as deposit reach to $145,467,000,102,655,000$ and 115,415 million rupiah, respectively. Moderate growth has been shown in 2012 whereby asset, financing and deposit shows $34.65 \%, 45.8 \%$ and $27.81 \%$, respectively.

Table 1 reveals that the growth of Islamic banking asset is around 20 to 40\% a year and for 2010 and 2011, the growth even reached more than $49 \%$. While the growth of Islamic banking industry is important, equally important is whether the market share of Islamic banking industry increase. These two things are different. Although there exist growth in Islamic banking industry, it does not mean that the market share is automatically increased. If in the case whereby conventional banking industry grows in a much faster rate then, the market share of Islamic bank will decrease. 
Table 1.

Performance of Islamic Banks in Indonesia

\begin{tabular}{|c|c|c|c|c|c|c|c|}
\hline \multirow[t]{2}{*}{ Year } & \multirow[t]{2}{*}{$\begin{array}{l}\text { Actual } \\
\text { Market } \\
\text { Share }^{2}\end{array}$} & \multirow[t]{2}{*}{ Asset $^{a}$} & \multirow[t]{2}{*}{ Financing $^{b}$} & \multirow[t]{2}{*}{ Deposit $^{c}$} & \multicolumn{3}{|c|}{ Growth (\%) } \\
\hline & & & & & Asset & Financing & Deposit \\
\hline 1992 & & 120,880 & 32,560 & 20,800 & & & \\
\hline 1993 & & 166,960 & 92,000 & 60,320 & 38.12 & 182.56 & 190.00 \\
\hline 1994 & & 246,080 & 188,800 & 132,880 & 47.39 & 105.22 & 120.29 \\
\hline 1995 & & 394,400 & 285,920 & 275,680 & 60.27 & 51.44 & 107.47 \\
\hline 1996 & & 515,200 & 310,480 & 396,560 & 30.63 & 8.59 & 43.85 \\
\hline 1997 & & 586,720 & 456,160 & 463,440 & 13.88 & 46.92 & 16.87 \\
\hline 1998 & & 479,200 & 317,040 & 391,920 & -18.33 & -30.50 & -15.43 \\
\hline 1999 & & 692,800 & 342,560 & 528,080 & 44.57 & 8.05 & 34.74 \\
\hline 2000 & & $1,790,168$ & $1,271,162$ & $1,028,923$ & 158.40 & 271.08 & 94.84 \\
\hline 2001 & & $2,718,770$ & $2,049,793$ & $1,806,366$ & 51.87 & 61.25 & 75.56 \\
\hline 2002 & & $4,045,235$ & $3,276,650$ & $2,917,726$ & 48.79 & 59.85 & 61.52 \\
\hline 2003 & $0.65 \%$ & $7,858,918$ & $5,530,167$ & $5,724,909$ & 94.28 & 68.78 & 96.21 \\
\hline 2004 & $1.20 \%$ & $15,325,997$ & $11,489,933$ & $11,862,117$ & 95.01 & 107.77 & 107.20 \\
\hline 2005 & $1.42 \%$ & $20,879,874$ & $15,231,942$ & $15,582,329$ & 36.24 & 32.57 & 31.36 \\
\hline 2006 & $1.58 \%$ & $26,722,030$ & $20,444,907$ & $20,672,181$ & 27.98 & 34.22 & 32.66 \\
\hline 2007 & $1.84 \%$ & $36,537,637$ & $27,944,311$ & $28,011,670$ & 36.73 & 36.68 & 35.50 \\
\hline 2008 & $2.11 \%$ & $49,555,122$ & $38,194,974$ & $36,852,148$ & 35.6 & 36.68 & 31.55 \\
\hline 2009 & $2.60 \%$ & $66,090,000$ & $46,886,000$ & $52,271,000$ & 33.37 & 22.75 & 41.84 \\
\hline 2010 & $3.24 \%$ & $97,519,000$ & $68,181,000$ & $76,036,000$ & 47.55 & 45.42 & 45.46 \\
\hline 2011 & $4.02 \%$ & $145,467,000$ & $102,655,000$ & $115,415,000$ & 49.17 & 50.56 & 51.79 \\
\hline 2012 & $4.58 \%$ & $195,018,000$ & $147,505,000$ & $147,512,000$ & 34.65 & 45.80 & 27.81 \\
\hline 2013 & $4.89 \%$ & $242,276,000$ & $183,534,000$ & $184,122,000$ & 24.23 & 24.82 & 24.42 \\
\hline 2014 & $4.75 \%$ & $261,927,000$ & $209,644,00$ & $198,376,000$ & 12.35 & 9.70 & 18.90 \\
\hline
\end{tabular}

Source: Bank Indonesia Shariah Banking Statistics, Various Issues and Harahap and Basri (2003)

In order for the central bank to develop the Islamic banking industry, a projection of Islamic banking market share is very important which later be used as the benchmark. Setting it to be too low will discourage the industry to perform well. Conversely, setting the target too high leads to also demotivate the industry. In short, the market

2 Based on the various report published by Bank Indonesia 
share target has to be designed in such a way that it encourages the industry to achieve it.

The problem with the projection of Islamic banking market share is that in many cases $^{3}$ the projection value is pretty much above the actual value. Table 2 shows the projection market share and the realization of market share (actual value).

Table 2.

Summary of Bank Indonesia Report on Islamic Banks and Realization of Market Share

\begin{tabular}{|c|c|c|}
\hline Report & $\begin{array}{c}\text { Projection } \\
\text { oflslamicbanking market } \\
\text { share }\end{array}$ & $\begin{array}{l}\text { Realization of } \\
\text { market share }\end{array}$ \\
\hline $\begin{array}{l}\text { Laporan Perkembangan } \\
\text { Perbankan Syariah } 2005 \text { (page } \\
\text { 53) }\end{array}$ & $\ln 2015 \rightarrow 8 \%$ & NA \\
\hline $\begin{array}{l}\text { Laporan Perkembangan } \\
\text { Perbankan Syariah } 2006 \text { (page } \\
\text { xi) }\end{array}$ & In dec $2007 \rightarrow 2-2.8 \%$ & $\begin{array}{l}1.72 \% \\
2007)\end{array} \quad$ (In nov \\
\hline $\begin{array}{l}\text { Laporan Perkembangan } \\
\text { Perbankan Syariah } 2006 \text { (page } \\
63 \text { ) }\end{array}$ & In dec $2008 \rightarrow 2.51 \%$ & $\begin{array}{l}2.0 \% \\
2008)^{4}\end{array} \quad(\operatorname{In} \quad \mathrm{Dec}$ \\
\hline $\begin{array}{l}\text { Laporan Perkembangan } \\
\text { Perbankan Syariah } 2007 \text { (page } \\
\text { 1) }\end{array}$ & $\begin{array}{l}\text { In dec } 2008 \rightarrow \quad 5 \% \\
\text { (Acceleration Program) }\end{array}$ & $\begin{array}{l}2.0 \% \\
2008)\end{array} \quad(\operatorname{In} \quad \mathrm{Dec}$ \\
\hline $\begin{array}{l}\text { Outlook Perbankan Syariah } \\
2012 \text { (page 18) }\end{array}$ & $\begin{array}{l}5 \% \text { will be achieved after } \\
2012 \text { (it does not mention } \\
\text { the month and year) }\end{array}$ & 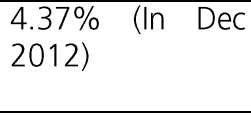 \\
\hline $\begin{array}{l}\text { Outlook Perbankan Syariah } \\
2013 \text { (page 29) }\end{array}$ & $\begin{array}{l}5 \% \text { will be achieved } \\
\text { during April-May } 2013 \\
\text { and } 6.5 \% \text { the end of } \\
\text { december }\end{array}$ & $\begin{array}{l}\text { 4.85\% (in March } \\
\text { 2013) }\end{array}$ \\
\hline
\end{tabular}

Sources: Various Sources from www.bi.go.id

In the annual report year 2006, it is projected that the market share will be $2.0-2.8 \%$ for the end of 2007 while in actual fact, it shows that the market share was $1.72 \%$. The same report shows that in December 2008, the projected market share target was $2.51 \%$ while the fact shows to be $2.1 \%$. Lastly the outlook Perbankan Syariah 2012 publication revealed that 5\% projected market share will be

3 Based on the various publication by Bank Indonesia

4 Despite the existence of subprime mortgage, Islamic bank in Indonesia was having low default rate. Moreover, the financing given by Islamic Banks is dominated in the domesticsector (the exposure to the international was limited). So there is negligible impact of subprime mortgage crisis to the Islamic bank in indonesian. (LPPS 2008, page v) 
achieved after 2012 (it does not mentioned the month and year) while the fact shows that at the end of 2012 the market share is still $4.5 \%$. The probable reason, especially for 2012 is on the fact that the deposit was taken by ministry of religion to be used to buy pilgrimage sukuk (Islamic bonds) issued by government for the economic development.

The only report which project the market share target which may close to the realization is the "Outlook Perbankan Syariah 2013" on page 29. It is projected that $5 \%$ target will be achieved in April or May 2013. This study has calculated that in March 2013, the realization market target is $4.85 \%$. Hence the target of $5 \%$ in April or May 2013 might be possible.

\section{THEORY}

Basically, there are three types of forecasting based on the time scale involved in the forecast i.e. short term, medium and long term forecast. The actual definition of short, medium and long term really depends on the cases being studied. Dealing with the business decision, short term forecast corresponds to up to 3-6 months, medium extends the time scale up to 2 years, while long term forecast usually involves of longer than 2 years. Time series forecasting methods especially perform well for short-term forecasting where the past information (series pattern) of certain variable is a good indicator of its future behaviour (Makridakis, Wheelwright and Hyndman,1998).

While this study has not enable to gather the relevant information on the methods used by Bank Indonesia to project the Islamic banking market share, this paper attempt to introduce theory namely Spline and Auto-ARIMA. The Auto-ARIMA examines standard ARIMA models using automatic algorithm which guarantee to obtain a model with lowest AIC. It then solve a problem of order selection in standard ARIMA procedure, which frequently become a problem in practice. ARIMA Box-Jenkins belongs to the class of autoregressive process that is normally used for generating short term forecasting.

ARIMA model has also been successfully applied in many financial case, see Meyler et al. (1998), Sekine (2001), Callen and Chang (1999) for application of ARIMA in predicting Inflation in some countries. Ginters (2009) has applied ARIMA for predicting Latvias's 
GDP. Kutsev et al. (1996) used ARIMA for forecasting future rate in some stock exchange market. Yuliani (2012) compares ARIMA and transfer function for predicting the asset and financing of Islamic banking in Indonesia. Khan (2010) uses ARIMA to forecast the growth of Islamic banking in Pakistan

Spline method belongs to nonparametric approach. Some researchers have applied Spline model for prediction such as smoothing and forecasting mortality rates with P-Splines (Carrie, 2002), Forecasting Hourly Electricity Demand Using Time-Varying Splines (Harvey and Koopman, 1993), Local Linear Forecasts Using Cubic Smoothing Splines (Hyndmann et al., 2002), Application of multivariate adaptive regression Splines (mars) to simulate soil temperature (Yang et al. 2004). Ba et al. (2008) usues Spline for electricity load forecasting. Another application in wather prediction has been applied by Price and MacPherson (1973). Pienaar and Choudry (2009) applied Spline to fit the term structure of interest rate.

Nevertheless, ARIMA and Spline models are basically designed for a stationary series, and hence they are incapable to generate better forecasts in case of structural breaks, shifts or outliers in the series. Some models have been introduced to specifically taking into account the presence of break, shift or outlier. See Tsay (1988) for detail of the models.

The study pertaining to the forecasting the banking asset especially Islamic banking asset is rarely to be found. Forecasting methods are used in the banking issues are on the prediction of banking crises, forecasting of loan loss given default, etc. Celik and Karatepe (2007) have done study on forecasting banking crises via neural network models in the case of Turkish Banking and it found out that the method is effective in the case of evaluating and forecasting banking crises. Forecasting bank loans loss given default is another example on the use of forecasting method in the context of banking issue. Bastos (2010) argue that estimation of the loss given default is important with the objective of following the new Basel Capital Accord on the credit risk issue. He evaluates the ability of a parametric fractional response regression to forecast the bank loan credit losses. Its results suggest that the method (regression trees) is the alternative to parametric models in modelling and forecasting loss given default. 
To the best of author knowledge, there is no study in forecasting the market share of Islamic bank. There are several reasons for this, first is there exist limited countries in which the Islamic banks have long been established while the use of forecasting require substantial number of data. Second, so far, among all countries only Malaysia and Indonesia can be identified as having a more comprehensive data, but yet study on the forecasting the market share still could not be found. This paper attempts to show alternative method which shall be adopted.

We believe these two methods (Spline and Auto-ARIMA) are revealing result which pretty much close to the realization of the market share. The following chapters are the relevant literatures review which also include the explanation of the methods used. Following it, this study described the result and analysis. While attempting the projection to the future, we also assume that the government play an important role in developing the Islamic banking industry. In this study, we create silmulation if government regularly deposite $1 \%$ of national budget in the Islamic banking industry. This paper ends with conclusion and recommendation.

\section{METHODOLOGY}

- Data and analytical methods

Data examine are asset of Islamic banks, asset of conventional banks and National Government Budget.The data used in this study have been collected from several sources such as Bank Indonesia and Finance Ministry of Indonesia. This research uses quantitative approach to analyze the data in order to answer the research questions. The steps of the analysis can be described as follows:

- $\quad$ Realistic target for the future of Islamic Banking

This part performs the forecasting results of future Islamic Banking using quantitative methods namely Spline and AutoARIMA. Both methods are performed as an automatic forecasting method in which the forecasts are generated from models that are chosen by minimizing the error forecast, regardless of the model assumptions. In fact, these two automatic forecasts are 
very simple to apply and have been used in many cases. The results of this analysis will be compared with Bank Indonesia projections that have been published earlier.

- Simulation

Simple simulation will be performed in order to give an insight about the projection has been set by the Bank Indonesia. Moreover, based on the results of the previously mentioned analysis, we will show whether the projection is realistic or overvalue.

This section briefly describes two quantitative methods used in this paper i.e. Automatic ARIMA (Auto-ARIMA) and Spline. Both methods are developed using the autoregressive framework and in most cases can generate good short run forecasts.

\subsection{Automatic ARIMA (Auto-ARIMA)}

Autoregressive Integrated Moving Average (ARIMA) model introduced by Box and Jenkins (1976) is still become a powerful method in time series data forecasting, in particular of short period forecasts. In fact, ARIMA has been used to forecast some cases either in short or long term periods with a good forecasting accuracy such as in Niu et al. (2010), Papagiannaki et al. (2003) among others. The ARIMA $(p, d, q)(P, D, Q)^{S}$ model has the following general form:

$$
\begin{array}{r}
(1-B)^{d}(1-B)^{D S}\left(1-\emptyset_{1} B-\cdots-\emptyset_{p} B\right)\left(1-\Theta_{1} B-\cdots-\Theta_{P} B\right)^{S} y_{t} \\
=\left(1-\theta_{1} B-\cdots-\theta_{q} B\right)\left(1-\Phi_{1} B-\cdots-\Phi_{Q} B\right)^{S} a_{t}
\end{array}
$$

Where $p$ and $q$ are the order of $A R$ and MA respectively, while $P$ and $Q$ are the order of seasonality in AR and MA term. $B$ is the backshift operator. The ARIMA modeling process involves of several procedures as follows:

- Time series identification and order selection

This step is done by performing the time series plot of the dataset in order to check whether the series has reached a stationary condition both in mean and variance level. Data differencing will be necessarily to do if the series shows an instationary pattern in the mean level. Moreover, transformation to the data will be required if one observes instationarity in the variance level. 
Another way to check the stationarity is by performing unit root test developed by Dickey and Fuller (1979) or the other approaches. After getting a stationary series, plots of Autocorrelation Function (ACF) and Partial Autocorrelation Function (PACF) are necessarily to be performed for order selection.

- Parameter estimation and testing

Having identified the possible models through the order, the parameters of the model have to be estimated. There are several methods can be used to estimate the parameters such as Conditional Least Square, Maximum likelihood as well as nonlinear estimation. The use of the method depends on the complexity of the model. The estimated parameters need to be tested in order to determine whether the order guess yields on significant parameters. Standard hypothesis testing with the t-statistics can be applied to the test.

- Diagnostic checking

Diagnostic checking means that we need to confirm whether the required assumptions in the modeling process are satisfied. The assumptions include of white noise and normally distributed residual of the model. White noise means that the residuals are independent and identical. It can be checked by performing the several tests such as L-Jung Box test or plotting the ACF of residuals. While the normality assumption can be tested by standard method such as Kolmogorov-Smirnov test, Anderson Darling, etc. If the residuals satisfy these assumptions, the ARIMA model is ready to use for forecasting. However, if one or both assumptions are violated, further analysis has to be carried out until we obtain a model that satisfies the assumptions.

The general process of ARIMA modeling can be summarized in Figure 1. Modeling with ARIMA is somehow trivial. It means that the models which satisfy the assumption might be more than one model. In this case the best model will be chosen by looking at the minimum error resulted from the models. A common problem in applying ARIMA models for forecasting is that the order selection process is 
usually difficult to be identified. To cope with this problem, there have been several attempts to automate ARIMA modeling e.g Hannan and Rissanen (1982) proposed a method to identify the order of an ARMA model for a stationary series by fitting a long autoregressive model to the data, and computing the likelihood of potential models via a series of standard regressions. The Hannan-Rissanen method has been extended by Gomez (1998). In this paper, the identification for the multiplicative seasonal ARIMA model is considered. An automatic procedure that uses BIC as the criteria for model selection is then proposed by Gomez and Maravall (1998). For a given series, the algorithm attempts to find the model with the minimum BIC. More advance algorithm for identification of more complex ARIMA model can be found in Liu (1989), Melard and Pasteels (2000). The AutoARIMA procedure applied in this research was developed based on the ARIMA procedure developed by Box and Jenkins (1976), introduced for the first time in M3 forecast competition. Makridakis and Hibon (2000) discuss in a comprehensive way about the Box-Jenkins procedure. 


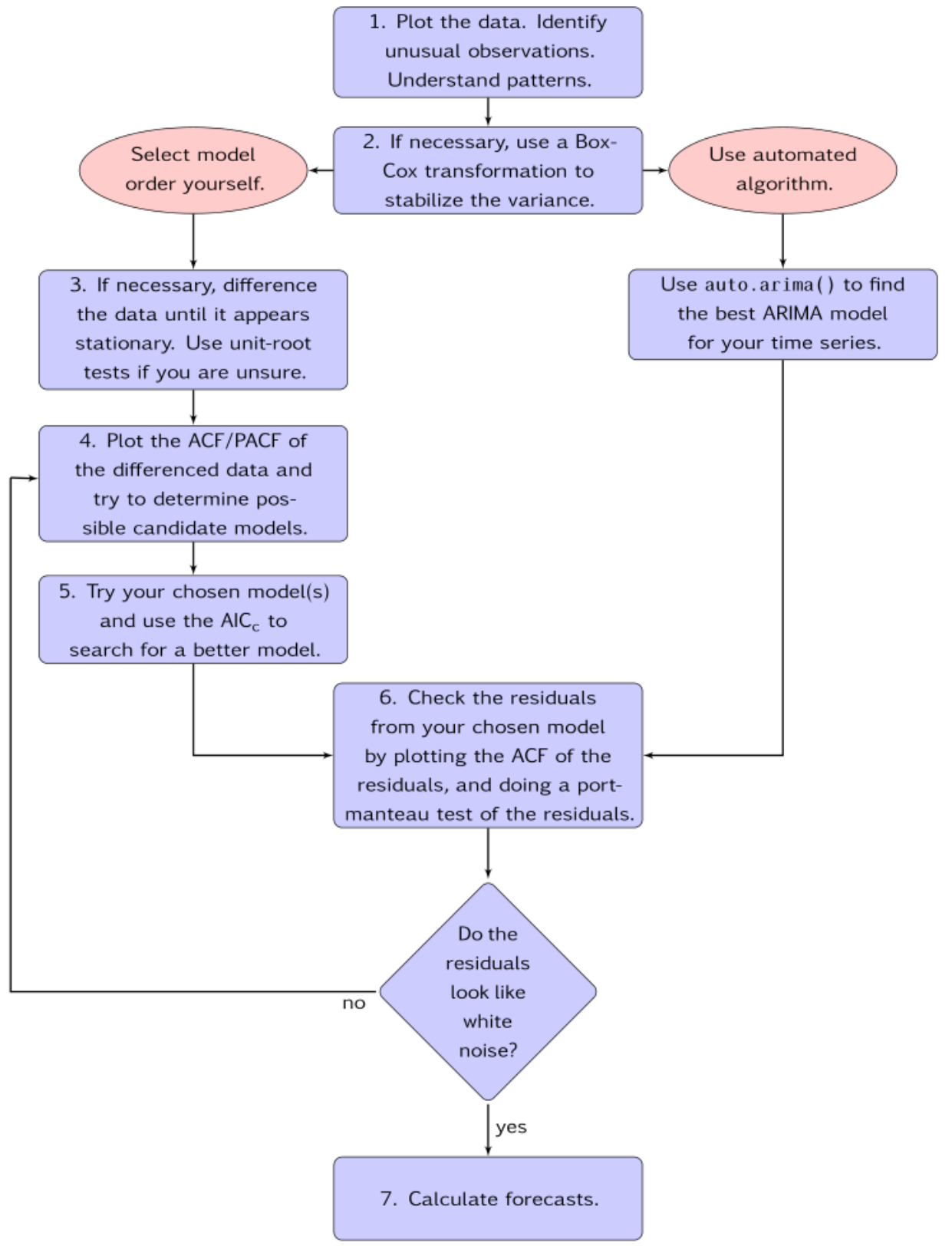

Figure 1.

Steps of ARIMA modeling

(source: Foreasting: Principle and Practice. An Online textbook Rob $J$ Hyndman and George Athanasopoulos) 
Modeling time series data using standard ARIMA procedure (for example Box Jenkins procedure) is a difficult task in some cases especially dealing with the order selection. The algorithm of automatic ARIMA (Auto-ARIMA) has been developed by Hyndmann and Khandakar (2008) in order to minimize the difficulty of conducting step 3 to 5 of the modeling process. The algorithm has been implemented in an open source $R$ software and (hereafter) referred to as Auto-ARIMA. The Auto-ARIMA solve this problem by applying stepwise procedure for traversing the model space yielding on a model which has lowest AIC among others. The algorithm in Auto-ARIMA has been developed to automatically select the best model. This is what the term "automatic" means. In summary, the algorithm in Auto-ARIMA can be described as follows:

Let define the general ARIMA $(p, d, q)(P, D, Q)^{S}$ model with $(p, d, q)$ is the non seasonal ARIMA order (i.e. Autoregressive, difference, and Moving Average order respectively), and $(P, D, Q)$ are the orders for seasonal ARIMA model with seasonality order of $S$. The main task of auto-ARIMA is to appropriate model with $p, d, q, P, D, Q$. If $d$ and $D$ are known, we can select order $p, P, q, Q$ via Information Criterion such as the AIC:

$$
A I C=-2 \log (L)+2(p+q+P+Q+k)
$$

Where $k=1$ if $c \neq 0$ and 0 otherwise and $\mathrm{L}$ is the maximized likelihood of the model fitted to the differenced data.

The difference order $d$ in ARIMA is choosen based on the result of KPSS unit root test, while the $D$ is chosen based on Canova and Hansen test (1995). In practice, the $D$ is selected first, and the $D$ is chosen by applying the successive KPSS unit root test to the seasonality differenced data (If differenced) or to the raw data (if not differenced). Once both differencing order have been selected, the $p, q, P, Q$ of the ARIMA model is chosen by minimizing AIC.

The appropriate order selection is done using a stepwise procedure for some possible models. As the combination of the possible model can be very high, it is not feasible to fit every potential model. The Auto-ARIMA algorithm is designed to traverse the space of models efficiently in order to achieve the model with lowest AIC. 
The stepwise algorithms are defined as follows (based on Hyndmad and Khandakar (2008)): suppose that we have seasonal model with the ARIMA order specified as ARIMA(p, $d, q)(P, D, Q) m$ with $q$ is limited to 1 to 3 , while $P$ and $Q$ can be 0 or 1 . The stepwise is run for all order combinations of ARIMA model. The higher the order, the bigger the number of the ARIMA model. The stepwise procedure is started with the model selection in under the following four possible models

- $\operatorname{ARIMA}(2, d, 2)$ if $S=1$, and ARIMA $(2, d, 2)(1, D, 1)$ if $S>1$

- $\operatorname{ARIMA}(0, d, 0)$ if $S=1$, and $\operatorname{ARIMA}(0, d, 0)(0, D, 0)$ if $S>1$

- $\operatorname{ARIMA}(1, d, 0)$ if $S=1$, and $\operatorname{ARIMA}(1, d, 0)(1, D, 0)$ if $S>1$

- $\operatorname{ARIMA}(0, d, 1)$ if $S=1$, and ARIMA $(0, d, 1)(0, D, 1)$ if $S>1$

For the defined models above, the model will be fitted using $c \neq 0$ If $d+D<1$, and $c$ is set to be zero if $d+D>1$. The model having minimum AIC will be chosen as the candidate, and it is called as current model.. For $m=1$, the model will be the standard $\operatorname{ARIMA}(p, d, q)$ without seasonality, while the model is $\operatorname{ARIMA}(p, d, q)(P, D, Q) m$ for $m>1$.

After having some models with the minimum AIC, we choose 13 models as the current models with the following specification where one of $p, q, P$ and $Q$ is allowed to vary by \pm 1 from the current model

- $\quad$ where $p$ and $q$ both vary by \pm 1 from the current model

- where $P$ and $Q$ both vary by \pm 1 from the current model

- where the constant $\mathrm{c}$ is included or excluded from the model

If we can find model with lower AIC, it will become the current model and the process is repeated until no lower AIC found. The selected model is the one used for the forecast. The selected model is the one used for the forecast. Hyndmad and Khandakar (2008) defined some constraints to avoid any problem with the convergence.

As the standard ARIMA procedure, the auto-ARIMA does not take into account the presence of outlier in the model. If it is the case, one should consider another model such as ARIMA with outlier (ARIMAX), etc. 


\subsection{Spline}

The Spline model forecasts the series by extrapolating the trend using a linear function estimated from the estimated time series. Some researchers have proven that the linear trend extrapolation performs well in practice. See for instance Makridakis \& Hibon (2000), Assimakopoulos \& Nikolopoulos (2000), and Hyndman \& Billah (2003) among others.

This paper uses cubic smoothing Spline for the extrapolation of the trend defined as the function which minimizes :

$$
\sum_{t=1}^{n}\left(y_{t}-f(t)\right)^{2}+\lambda \int\left(\left(f^{\prime \prime}(u)\right)^{2} d u\right.
$$

for a time series $y_{t}$. The rate of exchange between residuals is controlled by the smoothing parameter $\chi$ i.e. the sum of squared residuals and local variation represented by the integration part of the function. Fast algorithm proposed by Green and Silverman(1994) can be used to compute $\hat{f}(t)$ for any value of $\chi$. Large value of $\chi$ will yield on $\hat{f}(t)$ that is highly linear and small value will lead to wiggly function of $\hat{f}(t)$. The linear extrapolation of $\hat{f}(t) i$ s the point forecast.

The weighting mechanism in the forecasting procedure is normally applied in generating time series forecast, where the most recent observation will be assigned with high weight, while the weight for the distance past observation can be neglected. To deal with this within the framework of Spline model, this is done so that the smoothing parameter should not be very big for the forecasting purpose. The Spline algorithm has been developed in the open source $\mathrm{R}$ software by Hyndman and Khandakar (2008). Fitting the cubic smoothing Spline model is equivalent to fitting an $\operatorname{ARIMA}(0,2,2)$ model with a restricted parameter space. The Spline model has advantage compared to ARIMA i.e it provides a smooth historical trend as well as a linear forecast function.

\section{RESULTS AND DISCUSSION}

This section presents the results of the analysis using Spline and Auto-ARIMA in addition to the projection set by Bank Indonesia. Realization of the market share which shows the actual market share 
is also presented to enable us to calculate the error (the different between actualand projections. Hence there are total three cases which are from Bank Indonesia, and two from this study namely projection based on Spline and Auto-ARIMA methods.

This study has gathered all the necessary documents in which Bank Indonesia report the market share target for the following years. For instance, in report of Laporan Perkembangan Perbankan Syariah year 2006, there was a prediction of the target to be 2.0 to $2.8 \%$ in December 2007, etc. To the best of the authors knowledge, there are 5 periods of projections which were well documented in the official report. There are Dec 2007, Dec 2008, Dec 2012 and March 2013. The market share target of these years had been projected from the previous year documentation. The following table summarizes the best model for projecting the total asset of conventional bank and Islamic banking as well as the market share of Islamic banking. The error term is calculated based on out-sample projections confirming the realization of the market share in four past periods.

Table 3

Projection and Error by Bank Indonesia, Spline and Auto-ARIMA

\begin{tabular}{|c|c|c|c|c|c|c|c|}
\hline \multirow[t]{2}{*}{ Period } & \multirow{2}{*}{$\begin{array}{l}\text { Realiza- } \\
\text { tion of } \\
\text { market } \\
\text { share } \\
\text { (1) }\end{array}$} & \multicolumn{2}{|c|}{ Bank Indonesia } & \multicolumn{2}{|l|}{ Spline } & \multicolumn{2}{|c|}{ Auto-ARIMA } \\
\hline & & $\begin{array}{l}\text { Projection } \\
\text { (2) }\end{array}$ & $\begin{array}{l}\text { Error } \\
(3=1-2)\end{array}$ & $\begin{array}{l}\text { Project- } \\
\text { ion } \\
(4)\end{array}$ & $\begin{array}{l}\text { Error } \\
(5=1-4)\end{array}$ & $\begin{array}{l}\text { Project- } \\
\text { ion } \\
(6)\end{array}$ & $\begin{array}{l}\text { Error } \\
(7=1- \\
6)\end{array}$ \\
\hline $\begin{array}{l}\text { Dec } \\
2007\end{array}$ & $1.84 \%$ & $\begin{array}{l}2.0 \text { to } \\
2.8 \%\end{array}$ & $\begin{array}{l}1.84 \%- \\
2.00 \%= \\
-0.16 \%\end{array}$ & $1.68 \%$ & $\begin{array}{l}1.84 \%- \\
1.68 \%= \\
0.16 \%\end{array}$ & $1.73 \%$ & $\begin{array}{l}1.84 \% \\
- \\
1.71 \% \\
= \\
0.13 \%\end{array}$ \\
\hline $\begin{array}{l}\text { Dec } \\
2008\end{array}$ & $2.11 \%$ & $2.51 \%$ & $\begin{array}{l}2.11 \%- \\
2.51 \%= \\
-0.40 \%\end{array}$ & $1.95 \%$ & $\begin{array}{l}2.11 \%- \\
1.95 \%= \\
-0.16 \%\end{array}$ & $2.00 \%$ & $\begin{array}{l}2.11 \% \\
- \\
2.00 \% \\
= \\
0.11 \%\end{array}$ \\
\hline $\begin{array}{l}\text { Dec } \\
2012\end{array}$ & $4.58 \%$ & $\begin{array}{l}5 \% \text { will be } \\
\text { achieved } \\
\text { after } 2012\end{array}$ & $\begin{array}{l}4.58 \%- \\
5 \%= \\
-0.42 \%\end{array}$ & $5 \%$ & $\begin{array}{l}4.58 \%- \\
5.00 \%= \\
-0.42 \%\end{array}$ & $4.24 \%$ & $\begin{array}{l}4.58 \% \\
- \\
4.24 \% \\
= \\
0.34 \% \\
\end{array}$ \\
\hline $\begin{array}{l}\text { March } \\
2013\end{array}$ & $4.85 \%$ & $\begin{array}{l}5 \% \\
\text { April }\end{array}$ & $\begin{array}{l}4.85 \%- \\
5.00 \%= \\
-0.15 \%\end{array}$ & $4.7 \%$ & $\begin{array}{l}4.85 \%- \\
4.7 \%= \\
0.15 \%\end{array}$ & $4.48 \%$ & $\begin{array}{l}4.85 \% \\
- \\
4.48 \% \\
= \\
0.37 \%\end{array}$ \\
\hline \multicolumn{2}{|l|}{ RMSE } & \multicolumn{2}{|l|}{$0.310 \%$} & \multicolumn{2}{|l|}{$0.250 \%$} & \multicolumn{2}{|l|}{$0.265 \%$} \\
\hline
\end{tabular}


The projection of Bank Indonesia in this case is used as a benchmark. Based on the table above, in December 2007, the projection error from Bank Indonesia ${ }^{5}$ shows $-0.16 \%$ while Spline and Auto-ARIMA reveals $0.16 \%{ }^{6}$ and $0.13 \%{ }^{7}$, respectively. For December 2008 the projection error made from Bank Indonesia is $-0.40 \%$ while Spline and Auto-ARIMA shows $-0.16 \%$ and $0.11 \%$, respectively. Projection error of Bank Indonesia shows a bigger percentage as compare to other might be due to the overvalue of the Islamic banking market share projection. When the projection is overvalue, then the distance between the projected and the actual will be high that leads to the higher percentage of error. In December 2012, both Bank Indonesia and Spline forecast lead to the same error percentage of $0.42 \%$, which is higher than error generated from Auto-ARIMA of $0.34 \%$. Due to the fact that Spline involves of smoothing process which is sensitive to the slight change of the series behaviour, therefore, there is possibility that it will generate lower projection in longer lead times such as in the case of Spline projection in March 2013 (4.7\%) which is lower than December 2012 (5.0\%).

However, in order to conclude which among the methods is the best, we further calculate the Root Mean Square Error (RMSE). RMSE is the indicator to assess the error in a model. This is done by squaring the error to avoid the negative result then make the average of all the value and then make the squared root of that average value. The result shows that RMSE for Bank Indonesia, Spline and Auto-ARIMA are $0.310 \%, 0.250 \%$ and $0.265 \%$, respectively. RMSE for Bank Indonesia is the highest among the three methods while Spline model shows to have the lowest RMSE. Based on this result, this study concludes that Spline model can be the alternative method for the projection of Islamic Banking market share. However, Auto-ARIMA with its modest perfomance in this result may outperform Spline method in some cases.

This study also makes a projection on Islamic banking market share target for Dec 2013. As has been stated in Outlook Perbankan

5 It is the difference between actual market share (realization of market share) and Bank Indonesia projection. Or it is done by deducting coloumn 1 by coloumn 2

6 It is the difference between actual market share (realization of market share) and Bank Indonesia projection. Or it is done by deducting coloumn 1 by coloumn 4

7 It is the difference between actual market share (realization of market share) and Bank Indonesia projection. Or it is done by deducting coloumn 1 by coloumn 6 
Syariah 2013 page 29, the projection set by Bank Indonesia is 6.5\%. This study also adopts the same methods namely Spline and AutoARIMA. In order to do so, dataset spanning from January 2006 to December 2012 are adopted. The variables being examined are Total Asset of conventional Bank, and Total Asset of Islamic Banks. This two lead us to calculate the market share of Islamic banks.

Table 4 reveals that the Spline model outperforms the ARIMA model shown by the RMSE that are lower than that of ARIMA. This means that the projection produced from Spline model will be more accurate or yields lower bias than ARIMA. Hence in this case Spline is also better to be adopted than Auto-ARIMA.

This fact also concludes that Spine does always outperform Auto-ARIMA, both in the example of table 3 above, as well as in the example of table 4 below.

Table 4.

Best Model selected by ARIMA and Spline

\begin{tabular}{|c|c|c|c|}
\hline Series & Approach & Model & RMSE \\
\hline Total Asset of & Auto.ARIMA & ARIMA(0,2,1) & $5.752449 \mathrm{e}+13$ \\
\cline { 2 - 4 } $\begin{array}{c}\text { Conventional } \\
\text { Bank }\end{array}$ & Spline & $\lambda=5.2784$ & $3.410801 \mathrm{e}+13$ \\
\hline $\begin{array}{c}\text { Total Asset of } \\
\text { Islamic } \\
\text { Banking }\end{array}$ & Auto.ARIMA & ARIMA $(2,2,2)$ & $2.229107 \mathrm{e}+12$ \\
\cline { 2 - 4 } & Spline & $\lambda=3.09346$ & $1.347564 \mathrm{e}+12$ \\
\hline $\begin{array}{c}\text { Market Share } \\
\text { of Islamic } \\
\text { Banking }\end{array}$ & Auto.ARIMA & $\begin{array}{c}\text { ARIMA(0,1,0) } \\
\text { with drift }\end{array}$ & 7.3764 \\
\cline { 2 - 4 } & Spline & $\lambda=2.3237$ & 0.00040259 \\
\hline
\end{tabular}

The ARIMA model detects non-stationarity in the predicted series. This fact shows that the series moves on a non-constant level. Indeed, the total assets of both banking types as well as the market share of the Islamic banking industry have non constant growth within last 6 years.

The following figure depicts the projection of each series generated using the two models. For market share projection, we perform the optimistic projection as well. 
Optimistic projection in this case refers to the maximum value that can be reached under very good and stable financial market condition supporting the rapid development of Islamic banking in Indonesia.

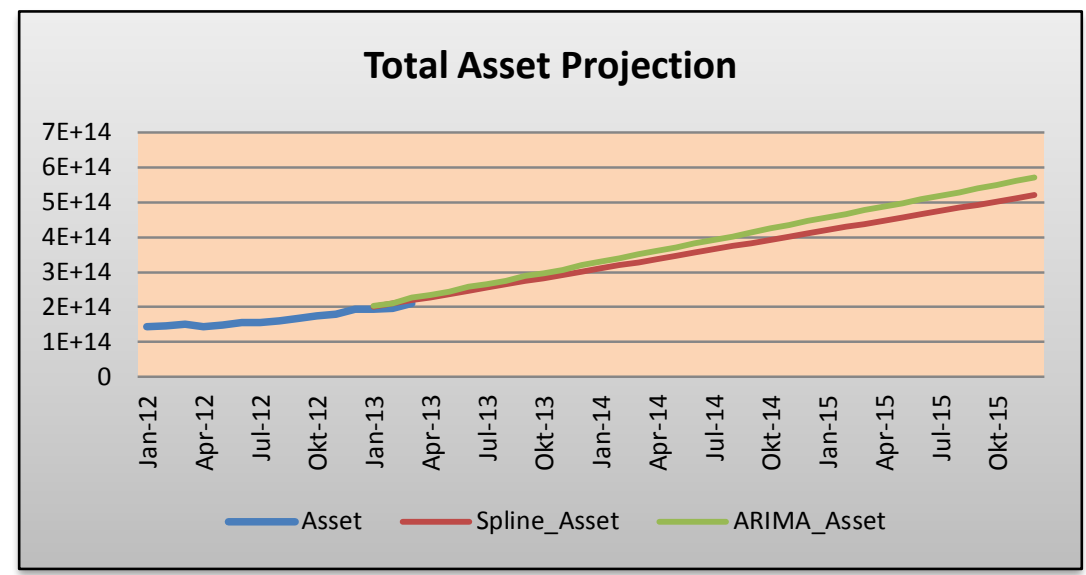

Figure 2.

Total Asset projection of Islamic Banking

Figure 2 compares the projection of total asset of Islamic Banking produced from Spline and ARIMA models. It can be seen that Spline model projection is consistently lower than projection from ARIMA. Bank Indonesia has projected the total asset in 2013 under moderate scenario will be Rp 269 Trillion, while ARIMA and Spline projections are 301.344 Trillion and 320.173 Trillion, respectively. These values increases in 2015 and reach more than 500 billion.

With regard to the market share projection using Spline and ARIMA model as depicted in Figure 3 and Figure 4, two projections are performed for each model, i.e. under moderate and optimistic scenarios.The projection showed that the market share of Islamic banking will reach 5 percent in April to May 2013 and it will increase up to $6.5 \%$ in the end of 2013. Spline model predict lower value that that issued by Bank Indonesia, i.e. 4.8\% under moderate scenario. Moreover, under optimistic scenario, it will reach up to $5.5 \%$ on May 2013. 
Considering the fact observed from the prediction of market share in January to March 2013, Spline model can predict very well, i.e. the actual share is very close to the moderate scenario although the prediction is slightly overvalued with level of bias prediction of 0.001 . Meanwhile, optimistic scenario seems to be too optimistic. The long horizon projection shows that the market share in 2015 will reach $8.5 \%$ under moderate scenario, while under optimistic scenario it will reach $16.7 \%$ market share. This shows that Spline and AutoARIMA can be the alternative to make projections.

The projection generated from ARIMA model has similar performance with Spline in early 2013. However, the market share increases with lower rate than generated from Spline, e.g. it suggests to the market share of $4.5 \%$ and $4.8 \%$ in May 2013 under moderate and optimistic scenario. These values are much lower than the projection generated from Spline as well as Bank Indonesia target. Using ARIMA, Bank Indonesia target of $6.5 \%$ market share will be achieved in the end of 2015 under optimistic scenario.

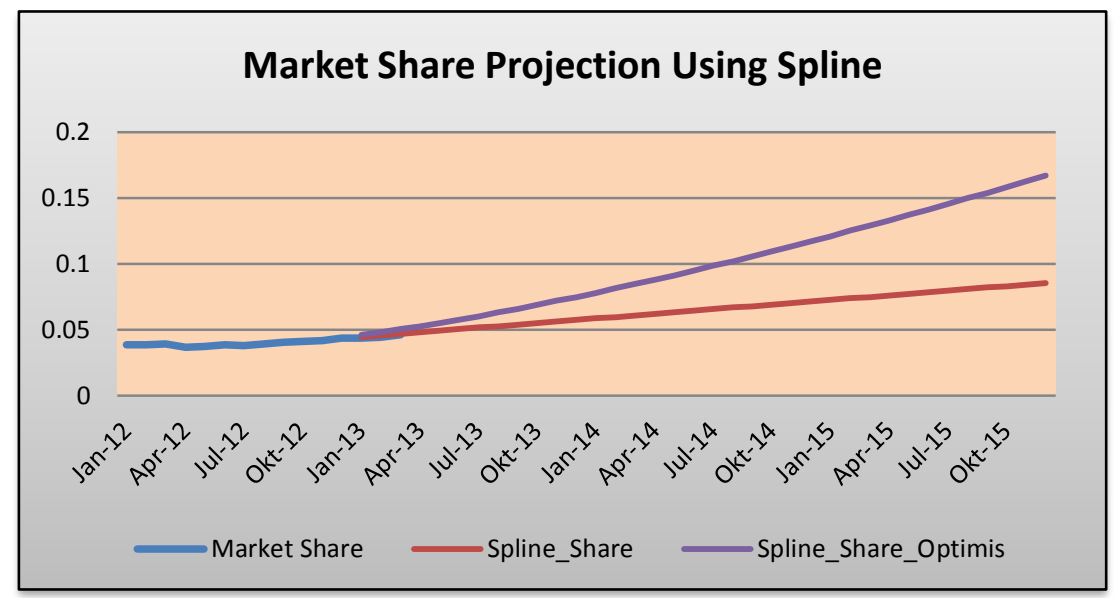

Figure 3.

Market Share Projection using Spline 


\section{Market Share Projection Using ARIMA}

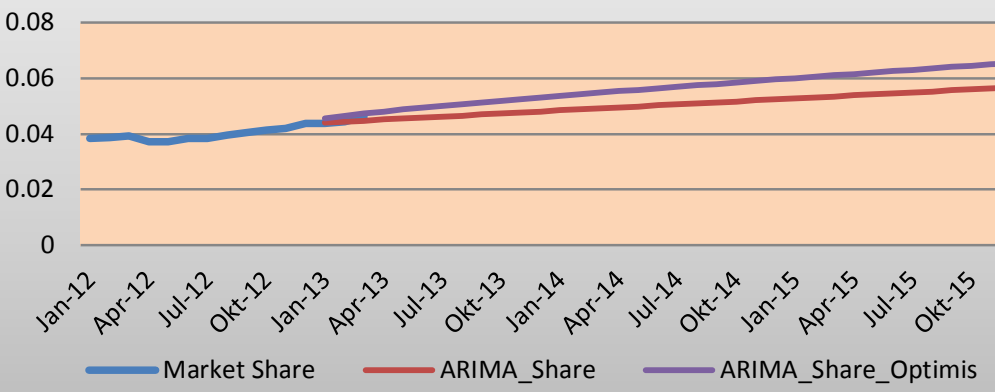

Figure 4.

Market Share Projection using ARIMA

The exact number of projections are listed in the following table. In this table, projection of of Bank Indonesia is also presented in addition to the two methods.

Table 5.

The Next 2 Years Projection on Islamic Banking Market Share

\begin{tabular}{|c|c|c|c|c|c|c|}
\hline \multirow[t]{2}{*}{ Period } & \multirow{2}{*}{$\begin{array}{c}\text { Actual } \\
\text { Market } \\
\text { Share }\end{array}$} & \multicolumn{2}{|c|}{ Spline Projection } & \multicolumn{2}{|c|}{$\begin{array}{l}\text { Auto-ARIMA } \\
\text { projection }\end{array}$} & \multirow{2}{*}{$\begin{array}{c}\text { Bank } \\
\text { Indonesia } \\
\text { Projection }\end{array}$} \\
\hline & & Moderate & Optimistic & Moderate & Optimistic & \\
\hline Jan-13 & $4.38 \%$ & $4.47 \%$ & $4.63 \%$ & $4.41 \%$ & $4.56 \%$ & \\
\hline Feb-13 & $4.44 \%$ & $4.58 \%$ & $4.83 \%$ & $4.45 \%$ & $4.65 \%$ & \\
\hline Mar-13 & $4.63 \%$ & $4.70 \%$ & $5.04 \%$ & $4.48 \%$ & $4.74 \%$ & \\
\hline Apr-13 & $4.76 \%$ & $4.82 \%$ & $5.27 \%$ & $4.52 \%$ & $4.81 \%$ & \multirow{2}{*}{$5.00 \%^{8}$} \\
\hline May-13 & $4.88 \%$ & $4.93 \%$ & $5.51 \%$ & $4.56 \%$ & $4.88 \%$ & \\
\hline Jun-13 & $4.90 \%$ & $5.05 \%$ & $5.77 \%$ & $4.59 \%$ & $4.95 \%$ & \\
\hline Jul-13 & $4.86 \%$ & $5.17 \%$ & $6.04 \%$ & $4.63 \%$ & $5.01 \%$ & \\
\hline Aug-13 & $4.88 \%$ & $5.28 \%$ & $6.31 \%$ & $4.66 \%$ & $5.08 \%$ & \\
\hline Sep-13 & $4.81 \%$ & $5.40 \%$ & $6.59 \%$ & $4.70 \%$ & $5.14 \%$ & \\
\hline Oct-13 & $4.87 \%$ & $5.52 \%$ & $6.89 \%$ & $4.74 \%$ & $5.20 \%$ & \\
\hline Nov-13 & $4.84 \%$ & $5.63 \%$ & $7.19 \%$ & $4.77 \%$ & $5.25 \%$ & \\
\hline Dec-13 & $4.89 \%$ & $5.75 \%$ & $7.50 \%$ & $4.81 \%$ & $5.31 \%$ & $6.50 \%^{9}$ \\
\hline Jan-14 & $4.78 \%$ & $5.87 \%$ & $7.81 \%$ & $4.84 \%$ & $5.37 \%$ & \\
\hline Feb-14 & $4.79 \%$ & $5.99 \%$ & $8.14 \%$ & $4.88 \%$ & $5.42 \%$ & \\
\hline Mar-14 & $4.88 \%$ & $6.10 \%$ & $8.47 \%$ & $4.92 \%$ & $5.48 \%$ & \\
\hline Apr-14 & $4.88 \%$ & $6.22 \%$ & $8.80 \%$ & $4.95 \%$ & $5.53 \%$ & \\
\hline May-14 & $4.85 \%$ & $6.34 \%$ & $9.15 \%$ & $4.99 \%$ & $5.59 \%$ & \\
\hline Jun-14 & $4.85 \%$ & $6.45 \%$ & $9.50 \%$ & $5.03 \%$ & $5.64 \%$ & \\
\hline Jul-14 & $4.92 \%$ & $6.57 \%$ & $9.85 \%$ & $5.06 \%$ & $5.70 \%$ & \\
\hline Aug-14 & $4.83 \%$ & $6.69 \%$ & $10.21 \%$ & $5.10 \%$ & $5.75 \%$ & \\
\hline Sep-14 & $4.75 \%$ & $6.80 \%$ & $10.58 \%$ & $5.13 \%$ & $5.80 \%$ & \\
\hline
\end{tabular}




\begin{tabular}{|c|c|c|c|c|c|}
\hline Oct-14 & $4.78 \%$ & $6.92 \%$ & $10.95 \%$ & $5.17 \%$ & $5.85 \%$ \\
\hline Nov-14 & $4.75 \%$ & $7.04 \%$ & $11.33 \%$ & $5.21 \%$ & $5.90 \%$ \\
\hline Dec-14 & $4.85 \%$ & $7.15 \%$ & $11.72 \%$ & $5.24 \%$ & $5.95 \%$ \\
\hline Jan-15 & $4.69 \%$ & $7.27 \%$ & $12.11 \%$ & $5.28 \%$ & $6.01 \%$ \\
\hline Feb-15 & $4.66 \%$ & $7.39 \%$ & $12.50 \%$ & $5.31 \%$ & $6.06 \%$ \\
\hline Mar-15 & $4.64 \%$ & $7.50 \%$ & $12.90 \%$ & $5.35 \%$ & $6.11 \%$ \\
\hline Apr-15 & $4.65 \%$ & $7.62 \%$ & $13.31 \%$ & $5.39 \%$ & $6.16 \%$ \\
\hline May-15 & & $7.74 \%$ & $13.72 \%$ & $5.42 \%$ & $6.21 \%$ \\
\hline Jun-15 & & $7.85 \%$ & $14.13 \%$ & $5.46 \%$ & $6.26 \%$ \\
\hline Jul-15 & & $7.97 \%$ & $14.55 \%$ & $5.49 \%$ & $6.30 \%$ \\
\hline Aug-15 & & $8.09 \%$ & $14.98 \%$ & $5.53 \%$ & $6.35 \%$ \\
\hline Sep-15 & & $8.20 \%$ & $15.40 \%$ & $5.57 \%$ & $6.40 \%$ \\
\hline Oct-15 & & $8.32 \%$ & $15.84 \%$ & $5.60 \%$ & $6.45 \%$ \\
\hline Nov-15 & & $8.44 \%$ & $16.28 \%$ & $5.64 \%$ & $6.50 \%$ \\
\hline Dec-15 & & $8.56 \%$ & $16.72 \%$ & $5.68 \%$ & $6.55 \%$ \\
\hline
\end{tabular}

Table 5 shows that in December 2013, the projected market share based on Spline moderate is $5.7 \%$ while the market share projection of Bank Indonesia is $6.5 \%{ }^{10}$. This study argued that Bank Indonesia is over optimistic about the target of the Islamic Bank market share in the end of 2013. ARIMA and Spline approximation shows that the target is possible to be achieved (or close to the Bank Indonesia target) only under very optimistic scenario. Notice that this very optimistic scenario can only be achieved if there exist interventions or acceleration programs.

This study further attempts to make the intervention available and make simulation so that $6.5 \%$ will be achieved or close to be achieved. The intervention is made by government by introducing $1 \%$ contribution of the total National Government Budget (NGB). The starting point is 2007, meaning that if the government consistently allocated $1 \%$ of the total NGB in a year to the Islamic Bank starting from 2007, the total market share of the Islamic banking should approximate the value presented in the plot.

To calculate the market share with the support of the government budget, we should transfer the amount of government budget (proportional to $1 \%$ of the NGB) from conventional bank to the Islamic bank leading to the increasing share of Islamic bank. Next is to divide the $1 \%$ of NGB into twelve to reach the monthly amount then add this to the monthly asset of Islamic banks. Following it, the same procedure of ARIMA and Spline are adopted. 
Result of simulation can be observed in the following figure. Projection on the December 2013, using the Spline method is $6.4 \%$ which is very much close to the $6.5 \%$ and with Auto-ARIMA, the value is even greater than $6.5 \%(7,01 \%)$. This means that in order to achieved $6.5 \%$ at the end of 2013 , government role is very important. The role of government in this case is to allocate $1 \%$ of NGB each year since 2007 to Islamic banks. The higher the percentage of National Government Budget (NGB) to be added to the Islamic Bank, the the higher the market share.

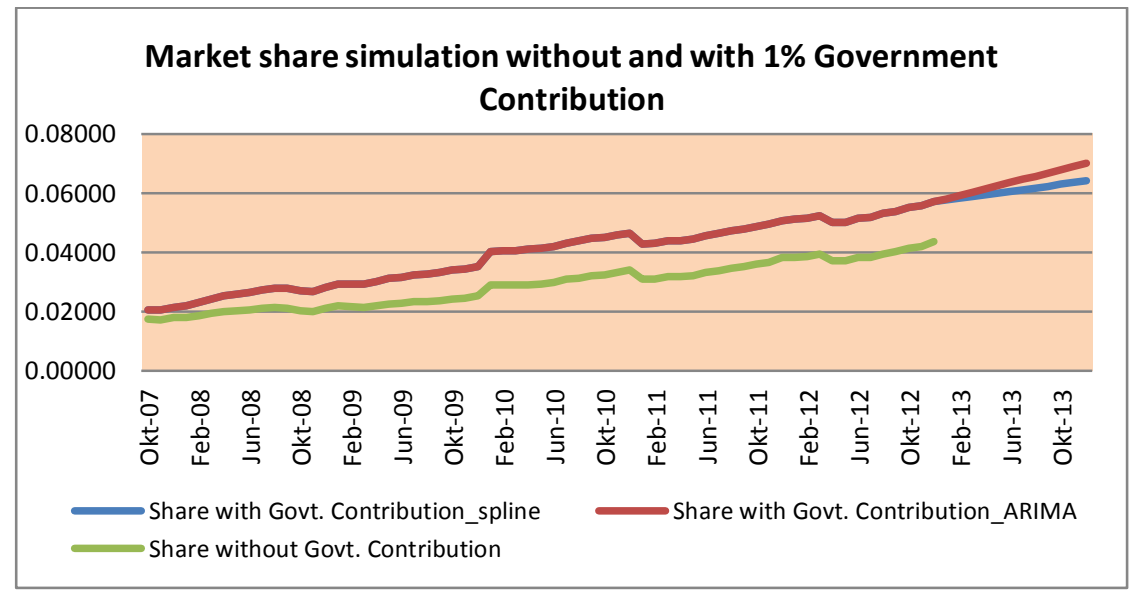

Figure 5. Market share simulation

\section{CONCLUSION}

This paper attempts to make a projection on the Islamic banking market share. It is done by introducing two methods namely AutoARIMA and Spline due to the fact that the market share projection set by Bank Indonesia seems to be overvalued. Projection by Bank Indonesia is important as the guideline for the Islamic bank. Too low projections would discourage the Islamic Bankers while too high creates pessimistic. Our result suggests that these two methods, especially Spline method, have revealed projection error which is less than that of Bank Indonesia. Hence these methods can be the alternative for the future projection of the Islamic banking market share. Furthermore, the role of government is very important to contribute to the Islamic Banking market share. The support of the 
government can be in many form, the policy of shifting the pilgrimage funds which previously in the conventional bank to Islamic bank is one of the form. Moreover, national government budget can also, partly, be deposited in the Islamic Bank. Having these policies, the Islamic banking market share shall increase significantly. 


\section{REFERENCES}

Assimakopoulos V and Nikolopoulos K. (2000). The Theta Model: A Decomposition Approach to Forecasting. International Journal of Forecasting, 16, 521-530.

Ba, A., Sinn, M., Goude, Y., and Pompey, P. (2008). Adaptive Learning of Smoothing Functions: Application to Electricity Load Forecasting. IBM Research Report.

Bastos. (2010). Forecasting Bank Loans Loss Given Default. Journal of Banking and Finance, 34, 2510-2517.

Box, G. and Jenkins, G. (1976). Time Series Analysis: Forecasting and Control. San Francisco: Holden-Day.

Carry, I. D., Durban, M. and Eilers, P. H. (2004). Smoothing and Forecasting Mortality Rates. Statistical Modelling, 4, 279-298

Callen, T., and Chang, D. (1999). Modeling and Forecasting Inflation in India. IMF Working Paper.

Celik, A. E and Karatepe, Y. (2007). Evaluating and Forecasting Banking Crises through neural network models: An application for Turkish banking Sector. Expert System with Applications, 33, 809-815

Data Pokok APBN 2006-2012. Ministry of finance web.

Dickey, D.A. and W.A. Fuller. (1979). Distribution of the Estimators for Autoregressive Time Series with a Unit Root. Journal of the American Statistical Association, 74, 427-431.

Ginters, B. (2009). Comparing forecasts of Latvia's GDP using simple seasonal ARIMA models and direct versus indirect approach. MPRA Working Paper.

Gomez, V. (1998). Automatic Model Identification in the Presence of Missing Observations and Outliers. Working paper D-98009, Ministerio de Economica y Hacienda, Direccision General de Analisis Programacion Presupuestaria.

Gomez, V. and Maravall, A. (1998). Programs TRAMO and SEATS, Instructions for the Users. Working paper 97001, Ministerio de Economica Hacienda, Direccision General de Analisis Programacion Presupuestaria. 
Hannan, EJ and Rissanen, J. (1982). Recursive Estimation of Mixed Autoregressive-Moving Average Order. Biometrika, 69(1), 8194.

Harvey, A. and Koopman, S. J. (1993). Forecasting Hourly Electricity Demand Using Time-Varying Splines. Journal of the American Statistical Association, 88(424): 1228-1236.

Hyndman, R., and Khandakar, Y. (2008). Automatic time series forecasting: the forecast package for R. Journal of Statistical Software, 27(3).

Hyndman, R.J. and Billah, B. (2003). Unmasking the Theta Method. International Journal of Forecasting, 19(2), 287-290.

Hyndman, R. J.; King M. L.; Pitrun, I. and Billah, B. 2002. Local Linear Forecasts Using Cubic Smoothing Splines. working paper.

Ismal, R. (2013). Islamic Banking in Indonesia: New Perspectives on Monetary and Financial Issues. John Wiley and Sons Inc.

Khan, S. (2010), Assessing and Forecasting the Growth of the Islamic Banking in Pakistan Using ARIMA Model. Journal of Islamic Banking and Finance, 27(4).

Kutsev, S.V., Smirnov, A. E. and Sorocoumov, V.E. (1996). ARIMA model application for forecasting futures. Programbank.

Laporan Perkembangan Perbankan Syariah, www.bi.go.id. Various years.

Liu, L.M. (1989). Identification of Seasonal Arima Models Using a Filtering Method. Communications in Statistics: Theory \& Methods, 18, 2279-2288.

Makridakis, S and Hibon, M (2000). The M3-Competition: Results, Conclusions and Implications. International Journal of Forecasting, 16, 451-476.

Melard, G. and Pasteels, J.M. (2000). Automatic ARIMA Modeling Including Intervention, Using Time Series Expert Software. International Journal of Forecasting, 16, 497-508.

Meyler, A., Kenny, G., and Quinn, T. (1998). Forecasting Irish inflation using ARIMA models. MPRA Working Paper.

Outlook Perbankan Syariah 2012 and 2013 by Bank Indonesia Publication. 
Pienaar, R., and Choudry, M. (2009). Fitting the term structure of interest rates: the practical implementation of cubic Spline methodology. Deutsche Bank Research Report.

Price, G., and MacPherson, A.K. (1973). A numerical weather forecasting method using cubic Spline on a variable mesh. Journal of applied meteorology, 12.

Sekine, T. (2001). Modeling and Forecasting Inflation in Japan. IMF working Paper.

Yuliani, F. (2012). Forecasting of assets to depositor Funds and financing Islamic banking in indonesia using function transfer method. Thesis, Department of Statistics ITS. 